\title{
The Influence of Knowledge Sharing on Academic Performance
}

\author{
T. Yuniarsih *, K. Kusnendi, L.A. Wibowo \\ Universitas Pendidikan Indonesia \\ Bandung, Indonesia \\ *yuniarsih@upi.edu
}

\begin{abstract}
This research aims to understand the effect of knowledge sharing on academic performance. Two processes of knowledge sharing are distinguished: donating and collecting. This research is intended to contribute to academic institutions in improving academic performance. The sample in this study amounted to 346 samples consisting of students at the Indonesian Economy Building School (STIE INABA) by using probability sampling techniques. The analysis technique used is multiple linear regression. The variables studied are knowledge sharing (knowledge donating and knowledge collecting) and academic performance. There search findings indicate that knowledge donating and knowledge collecting are positively significant related to academic performance. Based on these results, a number of theoretical and practical implications are discussed, and suggestions for further research are presented.
\end{abstract}

Keywords-Knowledge Sharing; Academic Performance; Academic Performance

\section{INTRODUCTION}

Polri, in order to improve the ability of foreign languages in its institutional environment, has a Language School, known as Sekolah Bahasa (Sebasa). The presence of Sebasa Polri is very much needed to improve the capabilities of the National Police $\mathrm{HR}$ in mastering foreign languages. Sebasa has a position under the Indonesian National Police Training and Education Institute which teaches six languages, namely English, French, Arabic, Mandarin, Japanese, and Indonesian for Foreign Student Officer. In accordance with its vision, Sebasa Polri is expected to produce professional police personnel who have the ability to establish communication with international languages in carrying out their duties, both at home and abroad, so that they can become part of the world community (world class community). Sebasa Polri in an effort to realize the vision and mission, it requires the support of innovative human resources in carrying out their duties.

According to Ramamoorthy, Flood, Slattery, \& Sardessai that in the current era of rapid change, organizations face a greater demand from their environment to engage in innovative behavior to create and provide competitive services, and to lead the change process itself [1]. To complete tasks successfully, organizations rely on members of the organization to innovate, method, and operation. Innovative behavior of organizational members according also as important sources of organizational innovation and as drivers of sustainable competitiveness, which will eventually impact on organizational performance [2-5]. For Sebasa Polri, the innovative behavior of employees is also very important in carrying out their duties, so that they can produce members of the National Police who are able to master foreign languages well.

In optimizing the innovative behavior of employees in an organizational environment, factors that can encourage it are needed. One important factor needed to encourage the emergence of innovative behavior is transformational leadership. According to Pieterse, Knippenberg, Schippers, \& Stam, transformational leadership is also a source of inspiration and motivation for organizational members [6]. Both of these important sources in generating innovation behavior. The literature study conducted by Rosing, Frese, \& Bausch also showed that transformational leadership is a driver of innovative behavior [7]. While studies are conducted by Günzel-jensen, Hansen, Jakobsen, \& Wulff, Hansen and PihlThingvad also showed that transformational leadership is a determinant of innovative behavior $[8,9]$

Organizational learning is also a factor that is urgently needed to foster a positive climate for creating innovative behaviors of organizational members. Innovation comes from learning activities, so learning in an organizational environment must be strengthened so that each member of the organization can be motivated to learn and further make innovations that are useful for their work. The ability to recognize new values, disseminate and implement them in organizations is an important factor for creating innovation capabilities [10]. Eldor \& Harpaz also explains that the learning climate in an organization is important in encouraging competitiveness which is a reflection of the innovative behavior of organizational members [11]. Studies conducted by Lin \& Lee also proved that organizational learning is a factor that significantly influences innovative behavior [12]. Especially in the public environment, research conducted by Miao, Newman, Schwarz, and Cooper also showed the important role of leadership in influencing innovative behavior [13].

In addition to transformational leadership and organizational learning, both of which are external factors, organizational member engagement as an internal factor is also an important driving factor for the growth of innovative behavior. This is according to Maden because work attachments can increase the proactive behavior of 
the transformation of changing followers, organizations, or even whole nations. It involves leaders interacting with followers with respect to their emotions, values, ethics, standards, and long-term goals, and includes assessing followers' motives, satisfying their needs, and treating them as full human beings" [21].

Furthermore, Northouse provided a boundary for transformational leadership, namely, "transformational leadership is the process of person engages with others and is a connection that raises the level of motivation and morality in both the leader and the follower" [22]. While, Robbins and Judge provided an explanation of transformational leadership as follows: "transformational leadership is the leadership style that inspires followers to transcend followers self-interests for the good of the organization and is capable of having a profound and extraordinary effect on the follower's concern" [23].

Explanation of transformational leadership is also shared by Griffin \& Moorhead "transformational leadership refers to the leadership that goes beyond ordinary expectations by transmitting a sense of mission, stimulating learning experiences, and inspiring new ways of thinking" [24]. Transformational leaders also motivate their subordinates to go beyond their personal interests for the good of the group, "transformational leaders who motivate people to transcend their personal interests for the good of the group" [25]. In addition, Avolio and Bass identified four dimensions of transformational leadership [26]. First, ideal leadership. Second, inspirational motivation. Third, intellectual stimulation. Fourth, individualized consideration.

Based on the explanation above, it can be synthesized that transformational leadership is a process of influencing subordinates by trying to inspire and motivate subordinates to work beyond expectations and make changes in a positive direction as measured by indicators: encouraging change, encouraging innovation, inspiring, setting an example, developing potential subordinates, build self-confidence, develop new ways of thinking, ability to motivate, build positive relationships, and respect subordinates.

\section{Organizational Learning}

Hilgard and Bower were quoted as saying by Vera, Crossan, \& Apaydin, "organizational learning is the process of change in individuals and shared actions" [27]. Furthermore, George and Jones, "organizational learning refers to the process through which managers seek to increase organization members' desire and ability to make decisions that continuously raise organizational efficiency and effectiveness" [28].

Furthermore, according to Gill organizational learning is described as follows: (1) assimilating information, (2) translating information into knowledge, (4) applying knowledge to real needs, (5) receiving feedback to revise the information and reshape the knowledge [29]. Organizational learning is also related to the activity of new knowledge as stated by de Castro, Sáez, López, and Dorado, the following [30]: Organizational learning is the accumulation of new knowledge, widening the intellectual capital stocks, and thus
Daft stated, "transformational leadership is involved, complex processes that bind leaders and followers together in 
The research uses data analysis techniques that contain descriptive statistics, testing requirements analysis, and hypothesis testing (inferential statistics). To discuss the hypothesis in this study used path analysis (path analysis). According to Foster, Barkus, and Yavorsky, path analysis is a multiple regression technique for causal relationships between variables that not only discuss causal relationships but also ask questions about the minimum number of relationships (reciprocal direction) and direction [34]. To calculate the path analysis used by the SPSS program for Windows. To test the significance of the path coefficient using a t-test, which is compared with $\mathrm{t}$ table. If $\mathrm{t}$ count $>\mathrm{t}$-table, then $\mathrm{H} 1$ is accepted and Ho is rejected; conversely, if $\mathrm{t}$ counts <t-table, then $\mathrm{H} 1$ is rejected and Ho is accepted.

\section{RESULTS}

Description of research variables consisting of transformational leadership, organizational learning, workrelatedness, and innovative behavior are presented in descriptive statistics which include minimum scores, maximum scores, range (range), mean, mode, median, standard deviation, and variance.

Testing the analytical requirements used in this study include the normality test, linearity test, and regression significance test. The normality test in this study uses estimated error data. By using the Liliefors test, the data are declared normal if Lcount <Ltable, and the data are declared abnormal if Lcount> Ltabel. The following is a summary of the results of the normality test calculations for each estimated error.

TABLE I. SUMMARY OF ERROR ESTIMATED NORMALITY TEST

work is a condition of one's mind, emotions and behavior that are focused on work as measured by indicators, focusing on work, making work results more meaningful, full of dedication, maintaining the best results in work, enthusiasm in work, love working, hard work, active involvement, commitment to completing tasks, and diligent work.

\section{METHOD}

This research was conducted at the Polri Language School, which is the only Indonesian Police Language School located on Cipinang Baru Raya No. 25, East Jakarta. The time of the study starts with the preparation in January to April 2019. The affordable population of this study is the Polri Language School educator who helps 86 educators. From the results of the sample calculation above, it was determined that the number of study samples is 71 Polri Language School educators. ESTIMATED ERROR WITH LILLIEFORS TEST (LO)

\begin{tabular}{|l|l|l|l|l|}
\multicolumn{6}{|c|}{$\begin{array}{c}\text { Regression } \\
\text { Estimation Error }\end{array}$} & $\begin{array}{c}\text { Lcount } \\
(\text { Lo })\end{array}$ & $\begin{array}{c}\mathbf{L}_{\text {tabel }} \\
\boldsymbol{\alpha}=\mathbf{0 , 0 5}\end{array}$ & $\begin{array}{c}\text { Ltabel } \\
\boldsymbol{\alpha}=\mathbf{0 , 0 1}\end{array}$ & Conclusion \\
\hline Y on X1 & 0,084 & 0,077 & 0,090 & Normal \\
\hline Y on X2 & 0,046 & 0,077 & 0,090 & Normal \\
\hline Y on X3 & 0,036 & 0,077 & 0,090 & Normal \\
\hline X3 on X1 & 0,062 & 0,077 & 0,090 & Normal \\
\hline X3 on X2 & 0,052 & 0,077 & 0,090 & Normal \\
\hline
\end{tabular}

Meanwhile, to test the significance of regression using Analysis of Variance (ANOVA). If the value of Fcount> Ftable at the error rate $(\alpha)$ of 0.05 , then the regression equation is significant, and at the error rate $(\alpha) 0.01$, the equation is very significant. The results of the evaluation of regression significance for each influence of transformational leadership, organizational learning, and work linkages to innovative innovations are summarized in the following table:

TABLE II. SUMMARY OF LINEAR REGRESSION TEST RESULTS

\begin{tabular}{|c|c|c|c|c|c|}
\hline \multirow[t]{3}{*}{ Variable } & \multirow[t]{3}{*}{ Equation Model } & \multicolumn{3}{|c|}{ Linearity Test } & \multirow{3}{*}{ Conclusion } \\
\hline & & Fcount & \multicolumn{2}{|l|}{$F_{\text {table }}$} & \\
\hline & & & $\begin{array}{l}\alpha= \\
0.05\end{array}$ & $\begin{array}{l}\alpha= \\
0.01\end{array}$ & \\
\hline $\mathrm{Y}$ on $\mathrm{X}_{1}$ & $\hat{\mathrm{Y}}=102,06+0,246 \mathrm{X}_{1}$ & $\begin{array}{c}28,652 \\
1,206\end{array}$ & $\begin{array}{l}2,67 \\
1.54\end{array}$ & $\begin{array}{l}3,91 \\
1.84\end{array}$ & $\begin{array}{l}\text { Significant and } \\
\text { Linear }\end{array}$ \\
\hline $\mathrm{Y}$ on $\mathrm{X}_{2}$ & $\hat{\mathrm{Y}}=68,603+0,450 \mathrm{X}_{2}$ & $\begin{array}{r}69,995 \\
0,957\end{array}$ & $\begin{array}{l}2,67 \\
1,47\end{array}$ & $\begin{array}{l}3.91 \\
1.74\end{array}$ & $\begin{array}{l}\text { Significant and } \\
\text { Linear }\end{array}$ \\
\hline
\end{tabular}




\begin{tabular}{llrrll}
\hline Variable & \multirow{2}{*}{ Equation Model } & \multicolumn{3}{l}{ Linearity Test } & \multirow{2}{*}{ Conclusion } \\
\cline { 3 - 5 } & & & Fcount & $\mathrm{F}_{\text {table }}$ \\
\cline { 3 - 5 } & & \multicolumn{3}{c}{$\alpha=$} & $\alpha=n$ \\
& & 0.05 & 0.01 & \\
\hline $\mathrm{Y}$ on $\mathrm{X}_{3}$ & $\hat{\mathrm{Y}}=47,282+0.482 \mathrm{X}_{3}$ & 94,117 & 2,67 & 3,91 & Significant and \\
& & 0,759 & 1,45 & 1.70 & Linear \\
\hline $\mathrm{X}_{3}$ on $\mathrm{X}_{1}$ & $\mathrm{X}_{3}=143,892+0,259 \mathrm{X}_{1}$ & 16,199 & 2,67 & 3,91 & Significant and \\
& & 1,475 & 1,49 & 1,76 & Linear \\
\hline $\mathrm{X}_{3}$ on $\mathrm{X}_{2}$ & $\mathrm{X}_{3}=81,292+0,670 \mathrm{X}_{2}$ & 97,337 & 2,67 & 3,91 & Significant and \\
& & 1,489 & 1,47 & 1,74 & Linear \\
\hline
\end{tabular}

\section{A. Hypothesis Testing}

To accept the research hypothesis, structural analysis is divided into the following three structures :

Substructure equation 1: The results of the calculation of path coefficients obtained by the direct influence of transformational leadership, organizational learning and work engagement to innovative motivation.

$$
\begin{gathered}
\mathrm{Y}=\mathrm{Py} 1 \mathrm{X} 1+\mathrm{Py} 2 \mathrm{X} 2+\mathrm{Py} 3 \mathrm{X} 3 \\
\mathrm{Y}=0.149 \mathrm{X} 1+0.185 \mathrm{X} 2+0.477 \mathrm{X} 4
\end{gathered}
$$

Substructure equation 2: The results of the calculation of path coefficients obtained by the direct influence of transformational leadership, organizational learning on work engagement.

$$
\begin{gathered}
\mathrm{X} 4=\mathrm{P} 31 \mathrm{X} 1+\mathrm{P} 32 \mathrm{X} 2 \\
\mathrm{X} 4=0.134 \mathrm{X} 1+0.739 \mathrm{X} 2
\end{gathered}
$$

Path coefficients and tcount values can then be seen in the following path diagram :

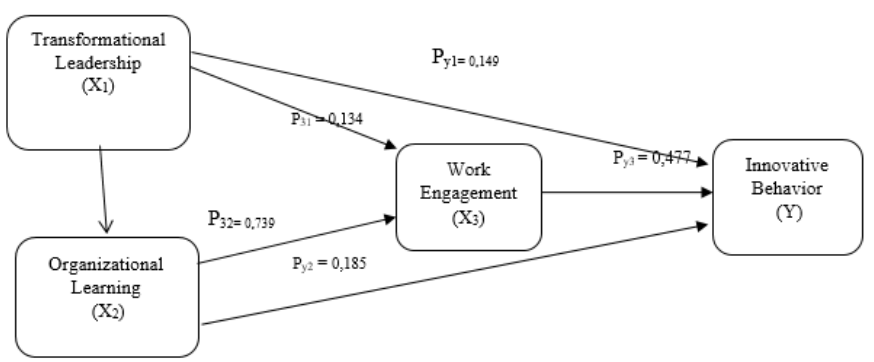

Fig. 1. Path coefficient and tcount leadership, learning and work organizations work on innovative behavior of the Polri Language School educators.

These results indicated that the theoretical models tested have represented or are in accordance with the structure of equations based on empirical data. Thus the results obtained from this study are in accordance with existing theories.

\section{B. Discussion}

Testing the first hypothesis proves that leadership has a positive direct effect on innovative behavior. This finding provides empirical evidence that an increase in transformational leadership carried out by a transformational leader will have an impact on increasing innovative behavior. These findings explain the relationship of transformational leadership to innovative behavior seen from the statement of Daft that, one style of leadership, referred to as transformational leadership, is particularly suited for bringing about change [21]. Top leaders who use a transformational leadership enhancing organizational innovation style, both directly, by creating a compelling vision, and indirectly, by creating an environment that supports exploration, experimentation, risk-taking, and sharing of ideas.

Testing the second hypothesis proves that organizational learning has a positive direct effect on innovative behavior. This finding provides empirical evidence that improving wellprogrammed organizational learning will increase innovative behavior, as described by Hartell, Zerbe, and Ashkanasy, following knowledge and learning processes have gained increased legitimacy in society and organizations [35]. They are known as an order to survive, innovate, and increase competitiveness [36].

Testing the third hypothesis proves that work linkages have a positive direct effect on innovative behavior. These results indicate that the high and low of innovative behavior is largely determined by the relationship of work that grows in the personal education staff. The theoretical findings above which state working work relationship directly influence innovative behavior are explained by Yalabik, Rayton, and Rapti, engaged employees show more personal initiative and innovative work behavior [37]. They tend to be more involved and socially connected to their work, which allows more opportunity to contribute to improvement and innovation. Gallup data indicates that $59 \%$ of engaged employees said that their jobs brought out their most creative ideas.

Testing the fourth hypothesis proves that transformational leadership has a positive direct effect on work relatedness. These results indicate that the high and low work relationship is determined by the power of transformational leadership. The above theoretical findings that state transformational leadership have a positive direct influence on work relevance, explained by Ayman and Lauritsen that "transformational leadership has a stronger positive relation with employee work engagement when the follower has positive characteristics" [38]. Transformational leadership has a stronger positive relationship with employee engagement if followers have positive characteristics. Barling also emphasized that "transformational leadership is associated with higher levels of employee work engagement. In turn, higher level of knowledge and initiative at the team level" [39].

Testing the fifth hypothesis proves that organizational learning has a positive direct effect on work relatedness. These results indicate that the high and low correlation of work is determined by conducive organizational learning. The theoretical findings above according to Bhaskar and Mishra are 
related to the association of organizational learning with work attachments explaining "two dimensions (connecting the organization to the environment and empowering employees) out of the seven dimensions of learning organizations as significant predictors of work engagement. The two dimensions of organizational learning, namely connecting organizations to the environment and empowering employees, are significant predictors of job participation [40]. Eldor and Harpaz also emphasized "employees' perceptions of organizational resources, such as perceived learning climate, as antecedent to employee engagement" [11].

Testing the sixth hypothesis proves that Transformational Leadership has a positive direct effect on Organizational Learning. These results indicated that high and low Transformational Leadership is largely determined by conducive organizational learning. The theoretical findings above according to Gordon are as follows: transformational leadership behaviors have a positive impact on organizational behaviors by inspiring organizational learning...leadership has a greater impact on organizational learning than servant leadership [41]. Nevertheless, both theories positively impact organizational performance through organizational learning.

\section{CONCLUSION}

The results of this study reinforce the theory that: First, improvement and improvement of leadership in using power and influence to focus on aspects of the quality of students on an ongoing basis to improve the expected innovative behavior for students. Second, improvement and improvement of organizational learning carried out by organizations in a wellprogrammed and conducive manner will enhance innovative behavior. Schools must have programs that innovate and are of high quality as values, principles, traditions, and ways of doing work behavior that can affect the workings of members of the organization acting to achieve the power of innovative behavior to students. Third, improvement and increased commitment to the task that is strong in the teacher will increase innovative behavior. Commitment to a strong task is the attachment and loyalty of a teacher in carrying out the tasks assigned to achieving superior innovative behavior according to the expectations and satisfaction of students. Fourth, improvement and improvement of leadership leads to the achievement of organizational goals. Fifth, the improvement and improvement of organizational learning carried out by organizations can apply good values, norms, traditions, and work behavior to members of organizational stakeholders as the power to carry out tasks according to the responsibilities given.

\section{ACKNOWLEDGMENT}

Thank you to the National Police Training Center for funding the entire series of studies until the preparation of this journal article.

\section{REFERENCES}

[1] N. Ramamoorthy, P.C. Flood, T. Slattery, and R. Sardessai, "Determinants of innovative work behaviour: development and test of an integrated model," Creat. Innov. Manag., vol. 14, no. 2, pp. 142-150, 2005 .

[2] F. Montani, F. Courcy, and C. Vandenberghe, "Innovating under stress: The role of commitment and leader-member exchange," J. Bus. Res., vol. 77, pp. 1-13, 2017.

[3] K. He, X. Zhang, S. Ren, and J. Sun, "Delving deep into rectifiers: Surpassing human-level performance on ImageNet classification," in The IEEE International Conference on Computer Vision, 2014, pp. 1026-1034.

[4] A. Newman, H.H.M. Tse, G. Schwarz, and I. Nielsen, "The effects of employees' creative self-e fficacy on innovative behavior: The role of entrepreneurial leadership," J. Bus. Res., vol. 89, no. April, pp. 1-9, 2018.

[5] X. Wang and M. Dass, "Building innovation capability: The role of top management innovativeness and relative-exploration orientation," $\mathrm{J}$. Bus. Res., vol. 76, pp. 127-135, 2017.

[6] A.N. Pieterse, D. Van Knippenberg, M. Schippers, and D. Stam, "Transformational and transactional leadership and innovative behavior: The moderating role of psychological empowerment," J. Organ. Behav., vol. 31, no. 4, pp. 609-623, 2010.

[7] K. Rosing, M. Frese, and A. Bausch, "Explaining the heterogeneity of the leadership-innovation relationship: Ambidextrous leadership," Leadersh. Q., vol. 22, no. 5, pp. 956-974, 2011.

[8] F. Günzel-jensen, J.R. Hansen, M.L.F. Jakobsen, and J. Wulff, “A twopronged approach? Combined leadership styles and innovative behavior," Int. J. Public Adm., vol. 41, no. 12, pp. 1-14, 2017.

[9] J.A. Hansen and S. Pihl-thingvad, "Managing employee innovative behaviour through transformational and transactional leadership styles," Public Manag. Rev., vol. 00, no. 00, pp. 1-27, 2018.

[10] A.C.L. Yeung, K. Lai, and R.W.Y. Yee, "Organizational learning, innovativeness, and organuzational performance: a qualitative investigation,” Int. J. Prod. Res., vol. 45, no. 11, pp. 2459-2477, 2007.

[11] L. Eldor and I. Harpaz, "A process model of employee engagement: The learning climate and its relationship with extra-role performance behaviors," J. Organ. Behav., vol. 235, no. October 2014, pp. 213-235, 2016.

[12] H. Lin and Y.-D. Lee, "A study of the influence of organizational learning on employees' innovative behavior and work engagement by a Cross-Level examination," EURASIA J. Math. Sci. Techmology Educ., vol. 8223, no. 1, pp. 3463-3478, 2017.

[13] Q. Miao, A. Newman, G. Schwarz, and B. Cooper, "How leadership and public service motivation enhance innovative behavior," Public Adm. Rev., pp. 71-81, 2018.

[14] C. Maden, "Linking high involvement human resource practices to employee proactivity: The role of work engagement and learning goal orientation," Pers. Rev., vol. 44, no. 5, pp. 720-738, 2015.

[15] U.A. Agarwal, "Linking justice, trust and innovative work behaviour to work engagement,” Pers. Rev., vol. 43, no. 1, pp. 41-73, 2014.

[16] S. Aryee, F.O. Walumbwa, Q. Zhou, and C.A. Hartnell, "Transformational leadership, innovative behavior, and task performance: test of mediation and moderation processes," Hum. Perform., vol. 25, no. 1, pp. 1-25, 2012.

[17] C.W.L. Hill and G.T.M. Hult, Global business today. New York: McGraw-Hill Education, 2016.

[18] M.A. White and G.D. Bruton, The management of technology and innovation: A strategic approach. Mason, $\mathrm{OH}$ : Thomson Higher Education, 2007.

[19] J. Tidd, J. Bessant, and K. Pavitt, Managing innovation: Integrating organizational change. Chichester: John Wiley \& Sons Ltd., 2005.

[20] E.R. Neiva, H. Mendonça, and M.C. Ferreira, "Innovation in organizations: Main research results and their practical implications," in Organizational Psychology and Evidence-Based Management, E. R. 
[32] G. Dessler, Human resource management. Essex: Pearson Education Limited, 2017.

Neiva, Ed. Brasilia: Springer International Publishing, 2017, pp. 157185.

[21] R.L. Daft, Manajemen (Terjemahan), 6th ed. Jakarta: Salemba Empat, 2007.

[22] P.G. Northouse, Leadership: Theory and practice. California: SAGE Publications, Inc., 2012

[23] S. Robbins and T.A. Judge, Organizational behavior, 15th ed. USA: Pearson Educational Inc, 2013.

[24] R.W. Griffin and G. Moorhead, Organizational Behavior: Managing People and Organizations. Ohio: South-Western Cengage Learning, 2014.

[25] T.S. Bateman, S.A. Snell, and R. Konopaske, Management. New York: McGraw-Hill Education, 2016.

[26] B.J. Avolio and B. M. Bass, Developing potential across a full range of leadership cases on transactional and transformational leadership, 1st ed. New York: Psychology Press, 2011.

[27] D. Vera, M. Crossan, and M. Apaydin, "A framework for integrating organizational learning, knowledge, capabilities, and absorptive capacity," in Handbook of organizational learning and knowledge management, 2nd ed., M. Easterby-Smith and M. A. Lyles, Eds. John Wiley \& Sons, 2011, pp. 153-180.

[28] J.M.G. George and G.R. Jones, Understanding and managing organizational behavior. New Jersey: Pearson Education, Inc.

[29] S.J. Gill, Organizational learning. Massachusetts: HRD Press, 2000.

[30] G.M. de Castro, P.L. Sáez, J.E.N. López, and R.G. Dorado, Knowledge creation processes: Theory and empirical evidence from knowledgeintensive firms. New York: Palgrave Macmillan, 2007.

[31] Z.S. Byrne, Understanding employee engagement: Theory, research, and practice. London: Routledge, 2014.
[33] R.L. Mathis, J.H. Jackson, and S.R. Valentine, Human resource management: Esential perspective. Mason, OH: South-Western Cengage Learning, 2016.

[34] J. Foster, E. Barkus, and C. Yavorsky, Understanding and using advanced statistics, no. November. London: Sage Publications, Ltd., 2006.

[35] C.E.J. Hartell, W.J. Zerbe, and N.M. Ashkanasy, Emotions in organizational behavior. New Jersey: Lawrence Erlbaum Associates Publishers, 2005.

[36] F.O. Walumbwa, S.J. Peterson, B.J. Avolio, and C.A. Hartnell, "An investigation of the relationships among leader and follower psychological capital, service climate, and job performance," Pers. Psychol., vol. 63, no. 4, pp. 937-963, 2010.

[37] Z.Y. Yalabik, B.A. Rayton, and A. Rapti, "Facets of job satisfaction and work engagement," Evidence-based HRM a Glob. Forum Empir. Scholarsh., vol. 5, no. 3, pp. 248-265, 2017.

[38] R. Ayman and M. Lauritsen, "Contingencies, context, situation, and leadership," in The nature of leadershipeadership, J. Antonakis and D. V Day, Eds. California: SAGE Publications, Inc., 2018, p. 154.

[39] J. Barling, The science of leadership: lessons from research for organizational leaders. USA: Oxford University Press, 2014.

[40] A. U. Bhaskar and B. Mishra, "Organisational learning \& work engagement: Study of an IT organization Published by: Stable URL: https://www.jstor.org/stable/24546996 By Contibution Organisational Learning \& Work Engagement : Study of an IT Organization,” Indian J. Ind. Relat., vol. 49, no. 3, pp. 541-550, 2019.

[41] G. Gordon, Leadership through trust: Leveraging performance and spanning cultural boundaries. Tyle: Palgrave Macmillan, 2017. 